https://doi.org/10.31470/2706-7904-2020-15-200-203

\title{
АКТИВНЕ СЛУХАННЯ ЯК ОДИН ІЗ ПРИЙОМІВ КОМУНІКАЦЇ̈ У ЗАЛАГОДЖЕННІ КОНФЛІКТУ
}

\section{Active Listening as One of the Techniques of Communication in Conflict Prevention}

\author{
Liliia Monastyrova \\ Associate Professor \\ National Academy of National Guard of Ukraine \\ monastyryova.lilia@gmail.com \\ https://orcid.org/0000-0002-4973-7308
}

\begin{abstract}
The abstract exposes the essence of the concept of Active Listening and Conflict. It is given reasons why the Active Listening as a communicative technique is important in conflict prevention. A general model of Active Listening with a mixed set of tactics and techniques is identified. Active Listening can be divided into verbal (questioning, clarification, reflection, summarization, paraphrasing and empathy) and non-verbal (gestures and mimics, eye contact, posture, showing your interest to the speaker) signs of listening. According to the results of observation this technique helps to control emotional side of the conversation and encourages the speaker to continue the conversation instead of acting aggressively.
\end{abstract}

Key words: active listening, conflict prevention, verbal and non-verbal signs.

\section{Вступ \\ Introduction}

Мова - міцна зброя впливу на учасників комунікації, ресурси якої дозволяють не просто описати певну ситуацію, але й передати необхідне комуніканту бачення світу, керувати його прийняттям ситуації й нав'язувати їй позитивну чи негативну оцінку. Комунікація є важливою складовою життя людини. Прийнято вважати, що мова $\epsilon$ основним засобом спілкування в суспільстві, але окрім мови, до засобів комунікації належать будь-які системи, які є засобом передачі інформації і можуть бути сприйняті іншим суб’єктом (Пелепейченко, 2018).

Поняття «конфлікт» дослідники розглядають у філософії, психології, соціології, теорії комунікації, а також у різних напрямах лінгвістики - 
психолінгвістиці, когнітивній лінгвістиці, прагмалінгвістиці, лінгвокультурології тощо. Проблема заслуговує на особливу увагу, бо дослідження сприятимуть уникненню або залагодженню конфліктів у різних сферах життя людини.

\section{Методи та методики дослідження}

Methods and Techniques of the Research

Для вирішення поставлених завдань було використано емпірично-теоретичні методи дослідження, зорієнтовані на аналіз, узагальнення і опис техніки активного слухання як одного з ефективних прийомів комунікації залагодження конфлікту.

\section{Результати}

\section{Results}

Конфліктні ситуації, які виникають внаслідок діаметрально-протилежних поглядів та інтересів різних соціальних верств сучасного суспільства $є$ потенційним джерелом масових заворушень, передумовою виникнення яких слугують певні нестабільні ситуації, напруження та виникнення відчуття тривоги і невпевненості у населення. Отже, саме тому, в умовах зростаючою конфліктності суспільства актуальності набуває пошук та реалізація комунікативних стратегій $i$ тактик спрямованих для залагодження конфлікту з окремими особами та 3 натовпом загалом у ситуаціях кризи.

Слід зазначити, що дуже часто ми не звертаємо багато уваги на такий комунікативний прийом як слухання, а саме на активне (рефлексивне) слухання. Слухання рефлексивне - стиль слухання, особливістю якого постає активний зворотний зв'язок для контролю точності сприйняття почутого (Загнітко, 2012: 329). Тобто замість того щоб «пасивно» слухати співрозмовника, слід повністю сконцентруватися на тому, що саме каже людина. Активне слухання є не тільки найвищим та найефективнішим рівнем слухання, але й особливою комунікативною технікою для досягнення успішної комунікації. Техніка активного слухання має вербальні і невербальні прийоми.

До невербальних прийомів активного слухання відносять: жести і міміку, за допомогою яких слухач підтверджує, що він чує та розуміє свого співрозмовника; зоровий контакт із співрозмовником, але не слід дивитися дуже пильно, бо це може бути прийнято досить вороже; відкриту позу, тобто не слід схрещувати руки при спілкуванні чи робити різкі рухи. Можна трішки наклонити голову у бік співрозмовника, щоб показати йому свій щирий інтерес до бесіди; показати 
співрозмовнику свою зацікавленість у розмові з ним, тобто не відволікатися під час розмови на інші справи, уникати дій, які можуть дратувати.

До вербальних прийомів активного слухання відносять: тактику задавання «відвертих питань» $з$ метою отримання більше інформації та показу щирого інтересу до співрозмовника. Наприклад: Як Ви вважаєте...? Ваша думка щзодо...? тощо; тактику «уточнення» 3 метою отримання більше інформації щодо певних конкретних питань. Для реалізації цієї тактики слід задавати уточнюючі питання чи повторювати слова співрозмовника 3 питальною інтонацією. Наприклад: Ви сказали щзо...будьласка; тактику «перефразування» 3 метою отримання більше інформації щодо певних конкретних питань, вираження зацікавленості, демонстрації уваги до того, що каже співрозмовник та перевірки вірності почутої інформації. Для реалізації цієї тактики слід стисло передати змість того, що було сказано своїми словами, але не зовсім точно, щоб у співрозмовника була змога продовжити пояснювати. Наприклад: Інакше кажучи, ..., Отже, ви мали на увазі ..., все вірно?; прийом емпатії з метою показати, що розумієте почуття іншої людини, проявити співчуття та показати повагу до думки співрозмовника. Для реалізації цього прийому слід зрозуміти емоції співрозмовника. Наприклад: Тобто Ви не бажаєте робити те, бо иче не задовільнить Ваші потреби y...? тактика «віддзеркалення» 3 метою демонстрації уваги та поваги до слів співрозмовника, підштовхнути до іншого бачення проблеми, дати змогу побачити себе 3 іншого боку. Для реалізації цієї тактики слід повторювати значущі фрази співрозмовника чи повторювати останні три слова, сказані людиною. Наприклад: $B u$ тільки-но згадали, щзо ..., Повертаючись до того, щуо Ви сказали про... тощо; тактику «підведення підсумків» 3 метою визначення рішення шляхом визбирування важливих фактів та ідей, демонструючи таким чином співпрацю та створюючи основу для подальшого діалогу. Для реалізації цієї тактики слід знову сформулювати головну думку співрозмовника та домовленості, яких було досягнуто і зробити відповідні висновки. Наприклад: Ми з Вами можемо домовитися про те, щзо ... , Як я зрозумів, ми з Вами домовилися про ... тощо.

Усе це свідчить про те, що на ефективність залагодження конфлікту впливає не тільки вибір низки комунікативних стратегій і тактик мовних засобів, але й вміння уважно слухати людину.

\section{Висновки \\ Conclusions}

Відтак, можна впевнено стверджувати, що активне слухання $є$ одним 3 найдієвих комунікативних засобів попередження конфлікту. Це допомагає створити 
атмосферу комфорту і довіри між співрозмовниками. Ця техніка допомагає керувати емоційною стороною бесіди, заохочувати співрозмовника до продовження розмови замість того, щоб перейти до агресивних дій та загострення конфлікту. Дослідження показало, що не варто наводити аргументів, намагаючись переконати іншу людину, критикувати іншу людину, критикувати думки або ідеї іншої людини чи силувати іншу людину щось робити або казати.

Вміння уважно слухати i почути людину $є$ однією 3 головних складових характеристики комунікативної компетентності.

\section{Література \\ References}

Загнітко, А. (2012) Словник сучасної лінгвістики: поняття і терміни. (Том 2). Донецьк: ДонНУ.

Леонтьев А.А. (1999). Основы психолингвистики.(2-е изд.). Москва: Смысл.

Розенберг М. (2019) Ненасильственное общение: Язык жизни. Перев. с англ. И. Серебрякова. Киев: София.

Skills You Need. Active Listening. Retrieved from https://www.skillsyouneed.com/ips/activelistening.html 